nog een verlaagde buisstroom worden vervaardigd. Dit geeft beelden met een wat lagere resolutie, maar dat is in deze gevallen goed genoeg. Deze aanpak kan de dosis beperken tot een aanvaardbaar niveau: in de orde van die van een panoramaopname, wat zeker bij kinderen van groot belang is. Wanneer u optreedt als verwijzend tandarts voor CBCT-opnamen bij kinderen, is het belangrijk om na te gaan of de apparatuur op het verwijsadres over deze lage-dosismogelijkheden beschikt en de operateur een 'lage-dosis-CBCT-mindset' heeft. Verder is het belangrijk dat de tandarts die de CBCT-opname vervaardigt de rechtvaardiging controleert en de onterechte indicaties voor $\mathrm{CBCT}$ eruit filtert.
Referenties:

Tyrologou S, Koch G, Kurol J. Location, complications and treatment of mesiodentes - a retrospective study in children. Swed Dent J. 2005;29(1):1-9.

Swamy DF, Barretto ES, Dessai SSR, Manuela K, D'Souza KM, Alex SA. The talon cusp anomaly - Review of the literature and treatment options. J Appl Dent Med Scienc. 2017; 3: 2

Schuurs A. Pathology of the hard dental tissues. 2012. John Wiley \& Sons, Oxford UK.

Lourenço L, Teixeira L, Costa B, Ribeiro M. (2003). Dental anomalies of the permanent lateral incisors and prevalence of hypodontia outside the cleft area in complete unilateral cleft lip and palate. Cleft Palate Craniofac J. 2003; 40(2): 172-175

European Commission, Radiation Protection N 172: Cone beam CT for dental and maxillofacial radiology. Evidence based guidelines. A report prepared by the SEDENTECT Project, 2011. www.sedentexct.eu/files/guidelines_final.pdf

Reinier Hoogeveen en Frédérique San Giorgi, ACTA, sectie Radiologie

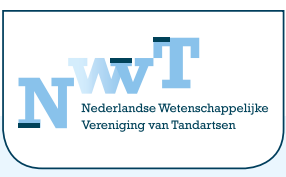

\title{
NWVT-CURSUS ‘OCCLU SENSE OF NO SENSE'
}

\section{Het belang van een goede occlusie}

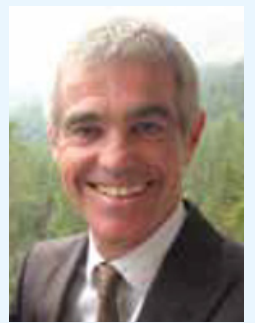

Occlusie en articulatie is een onderwerp dat terecht in de belangstelling staat van tandartsen. Het belang van een goede occlusie en articulatie laat zich niet makkelijk bewijzen: nuchter en logisch nadenken is gewenst. Peter Wetselaar zal in zijn voordracht 'Het belang van een goede occlusie' een reeks algemene aspecten kritisch met u doornemen. Op dit moment is er onvoldoende wetenschappelijk bewijs voorhanden om een specifiek occlusie- en/of articulatieconcept te adviseren bij restauratieve en/of prothetische behandelingen. Zelfs het veel gehoorde adagium dat hoektandgeleiding superieur zou zijn aan groepsgeleiding kan niet worden bewezen in relatie tot het comfort van de patiënt of de levensduur van restauraties. Wel is er overtuigend bewijs dat occlusie en articulatie geen rol spelen bij het ontstaan of onderhouden van temporomandibulaire klachten of bruxisme.

Door zorgvuldig te werken zijn we in staat duurzame restauraties te vervaardigen passend in de bestaande mondsituatie, waarbij uitvoerig ingrijpen in de occlusie en articulatie door mondzorgverleners veelal niet nodig is.

\section{De leerdoelen:}

U kunt benoemen:

- Wat het belang is van de grensposities van de bewegingen van de onderkaak.

- Wat het verschil en het belang is van maximale occlusie en centrale occlusie.

- Welke factoren een rol spelen bij de etiologie van bruxisme en TMD.

\section{De klinische toepassing van de T-scan; het meten van de timing van het tandcontact}

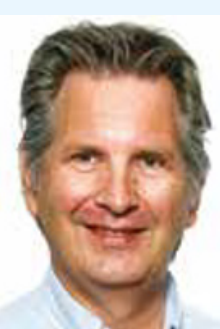

Tanden en kiezen groeien niet uit totdat ze gelijkmatig op elkaar passen. Met een T-scan zijn we voor het eerst in staat om nauwkeurig en reproduceerbaar de timing van het tandcontact te registreren. Daaruit blijkt dat premature contacten vaak debet zijn aan gnathologische en tandheelkundige problemen. Deze premature contacten zijn op geen enkele andere manier op te sporen en blijven zonder T-scan onopgemerkt. Verder kun je de krachtverdeling over de hele tandboog met een T-scan meten. Als voorbeeld: Met een T-scan kun je registreren of kostbare tandtechnische werkstukken op implantaten als eerste contact maken of de meeste kauwdruk krijgen. Dat is natuurlijk het laatste wat we willen.

De T-scan is een waardevol aanvullend diagnosticum, ook bij het onderzoek naar pijnklachten uitgaande van het bewegingsapparaat, maar het is geen panacee voor TMD.

De data die je met een T-scan verkrijgt zijn nogal complex. De leercurve is daardoor nogal lang.

Hugo Vreugdenhil zal in zijn voordracht 'De klinische toepassing van de T-scan; het meten van de timing van het tandcontact' ingaan op de technische werking van de T-scan, de procedure van het scannen en het analyseren van de data.

\section{De leerdoelen:}

Het verkrijgen van:

- Basiskennis van de technische werking van de T-scan.

- Kennis van de procedure van het scannen met de T-scan.

- Kennis van de analyse van de met een T-scan verkregen data. 